\title{
Paleolatitudes of the Kerguelen hotspot: new paleomagnetic results and dynamic modeling
}

\author{
M. Antretter ${ }^{\mathrm{a}, *}$, B. Steinberger ${ }^{\mathrm{b}}, \mathrm{F}$. Heider ${ }^{\mathrm{a}, 1}, \mathrm{H}$. Soffel ${ }^{\mathrm{a}}$ \\ a Institut für Geophysik, Theresienstr. 41, 80333 Munich, Germany \\ b Cooperative Institute for Research in Environmental Sciences (CIRES), University of Colorado at Boulder, Campus Box 216, \\ Boulder, CO 80309-0216, USA
}

Received 6 March 2002; received in revised form 28 June 2002; accepted 12 July 2002

\begin{abstract}
The Kerguelen Plateau, a Large Igneous Province in the southern Indian Ocean, was formed as a product of the Kerguelen hotspot in several eruptive phases during the last $120 \mathrm{Myr}$. We obtained new paleolatitudes for the central and northern Kerguelen Plateau from paleomagnetic investigations on basalts, which were drilled during ODP Leg 183 to the Kerguelen Plateau-Broken Ridge. The paleolatitudes coincide with paleolatitudes from previous investigations at the Kerguelen Plateau and Ninetyeast Ridge (the track of the Kerguelen hotspot) and indicate a difference between paleolatitudes and present position at $49^{\circ} \mathrm{S}$ of the Kerguelen hotspot. We show that true polar wander, the global motion between the mantle and the rotation axis, cannot explain this difference in latitudes. We present numerical model results of plume conduit motion in a large-scale mantle flow and the resulting surface hotspot motion. A large number of models all predict southward motion between $3^{\circ}$ and $10^{\circ}$ for the Kerguelen hotspot during the last $100 \mathrm{Myr}$, which is consistent with our paleomagnetic results.
\end{abstract}

(C) 2002 Elsevier Science B.V. All rights reserved.

Keywords: geomagnetism; paleomagnetism; Leg 183; paleolatitude; true polar wander; hot spots; mantle plumes; Kerguelen Plateau

* Corresponding author. Tel.: +49-89-2180-4231; Fax: +49-89-2180-4205. Until September 2002 at: CEREGE, University of Aix-Marseille 3, P.O. Box 80, Europôle de l'Arbois, 13545 Aix en Provence Cedex 4, France.

E-mail addresses: maria@geophysik. uni-muenchen.de (M. Antretter), bernhars@cires.colorado.edu (B. Steinberger), franz.heider@utanet.at (F. Heider),soffel@geophysik.unimuenchen.de (H. Soffel).

1 Present adress: Infineon Technologies, 9500 Villach, Austria.

\section{Introduction}

Whether or not and to what extent hotspots are fixed can give important information about the dynamics of the Earth's deep interior where they probably originate. Furthermore, the hotspot reference frame as it has been used to define absolute plate motions is only useful if any motions of hotspots are properly taken into account. The subject has therefore recently been investigated by several researchers: numerical models of motions of hotspots due to mantle flow have been presented [1,2]; paleomagnetic data $[3,4]$ and plate reconstructions 
[5-8] have been used to argue both for hotspot mobility and for hotspot fixity. Relative hotspot motion between hotspots in the Indian and Atlantic oceans has been reported to be a few $\mathrm{mm} / \mathrm{yr}$ [5]. In contrast, motion of hotspots in the Pacific region relative to hotspots in the Indo-Atlantic regions has been found to be a few $\mathrm{cm} / \mathrm{yr}[6]$.
A way to determine hotspot motion that does not directly depend on any plate motion models makes use of the characteristic remanent magnetization (ChRM) of basalts which have been produced by the hotspot: if secular variation is properly averaged out, if the hotspot is fixed, if the geocentric axial dipole (GAD) hypothesis holds,

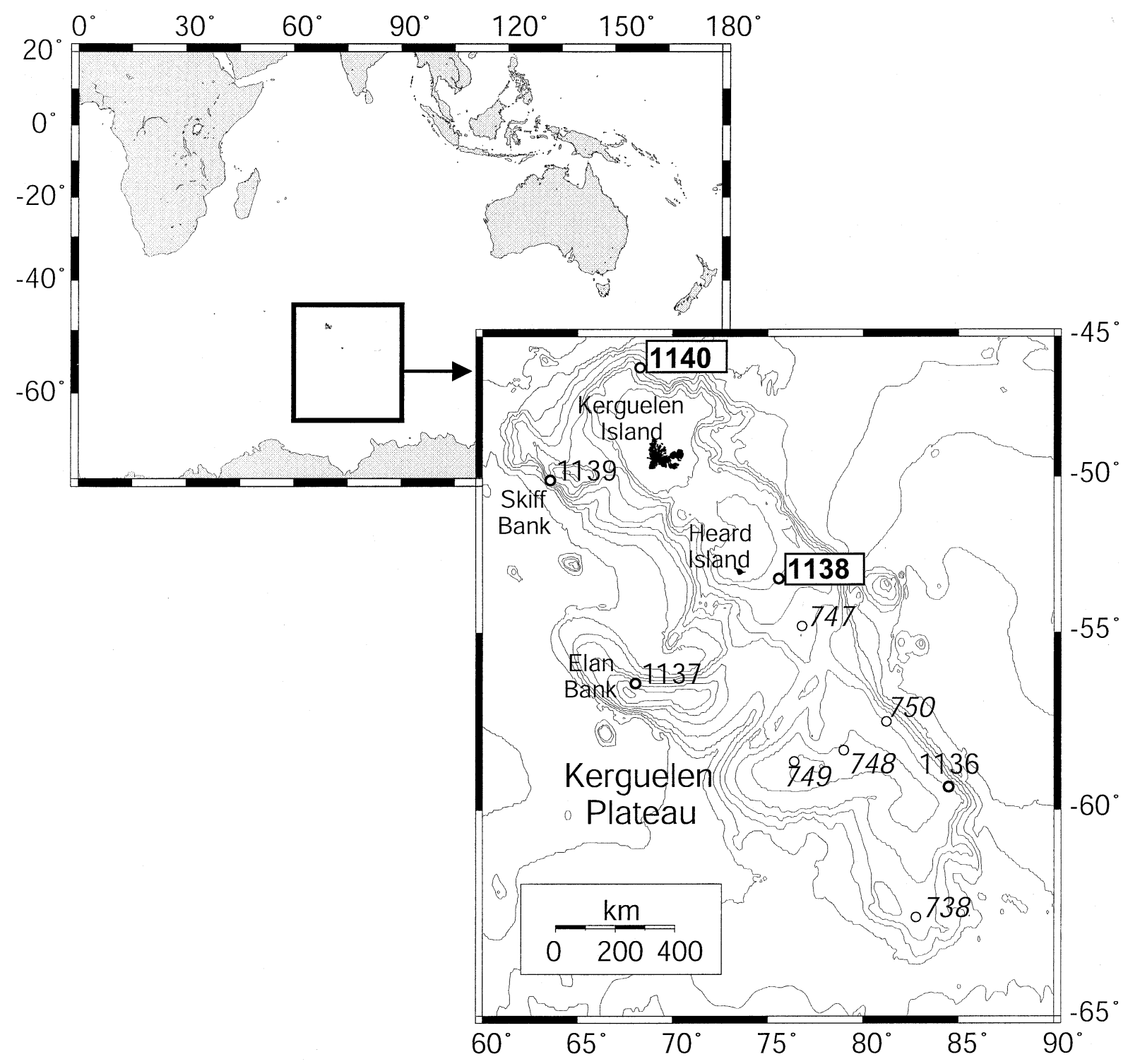

Fig. 1. Bathymetric map of the Indian Ocean showing the Kerguelen Plateau. Summary of ODP drill holes on the Kerguelen Plateau that recovered volcanic rocks (Leg 119: Site 738; Leg 120: Sites 747, 748, 749, and 750; Leg 183: Sites 1136, 1137, 1138, $1139,1140)$. Basalts of bold signed Sites (1138 and 1140) were used to paleomagnetically determine new paleolatitudes, which are presented here. Contour intervals $=500 \mathrm{~m}$. 
and if the rotation axis does not move with respect to the mantle (true polar wander, TPW), the inclination of the ChRM should remain constant and should correspond to the present-day latitude of the hotspot. If that is not the case, one or more of the conditions will not be fulfilled.

This paper contributes to the topic of hotspot motion by looking particularly at the Kerguelen hotspot, and it presents paleomagnetic data as well as modeling results. The Kerguelen hotspot in the southern Indian Ocean has produced the Rajmahal Traps, the Kerguelen Plateau, the Broken Ridge complex and the Ninetyeast Ridge since its origin approximately $120 \mathrm{Ma}$ ago. We present new paleomagnetic investigations of basalts of the Kerguelen Plateau (Fig. 1) that were drilled during ODP Leg 183 to the KerguelenBroken Ridge Plateau, yielding new paleolatitudes for the northern Kerguelen Plateau (NKP) and the central Kerguelen Plateau (CKP). Two curves of TPW that were independently derived from continental paleomagnetic data $[9,10]$ are used to compute one component of changes in hotspot latitude. In addition to this, the latitude change of the Kerguelen hotspot due to its motion in large-scale mantle flow is calculated. Combining both effects, we are able to compute changes in hotspot paleolatitudes and to compare predictions with the paleomagnetic results.

\section{Paleomagnetism}

During Ocean Drilling Program (ODP) Leg $183,144.5 \mathrm{~m}$ of massive lava flows were penetrated and $69.0 \mathrm{~m}$ of core was recovered on the

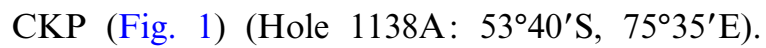
The basalt sequence can be separated into 21 lithologic units [11]. $87.9 \mathrm{~m}$ of pillow basalts with sediment layers between some pillow complexes have been penetrated and $49.1 \mathrm{~m}$ of core has been recovered on Site 1140, $270 \mathrm{~km}$ north of Kerguelen Island on the NKP (Hole 1140A: $47^{\circ} 56^{\prime} \mathrm{S}, 69^{\circ} 54^{\prime} \mathrm{E}$ ) (Fig. 1). ${ }^{40} \mathrm{Ar} /{ }^{39} \mathrm{Ar}$ radiometric data yield ages of $100.41 \pm 0.71$ and $34.30 \pm 0.59$ Ma for Sites 1138 and 1140, respectively [12].

Azimuthally unoriented discrete inch cores ( $n=151$ for CKP and $n=81$ for NKP) were drilled

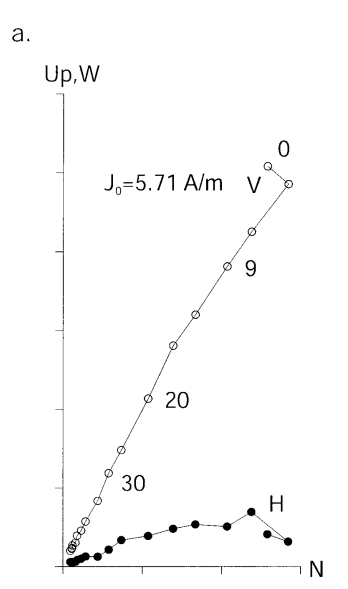

b. Up,N

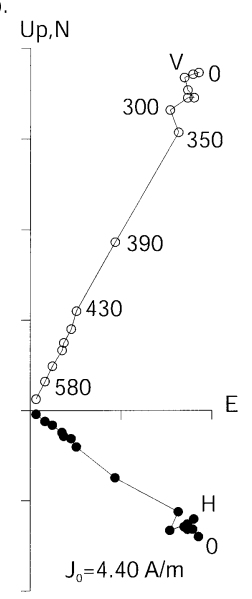

C.

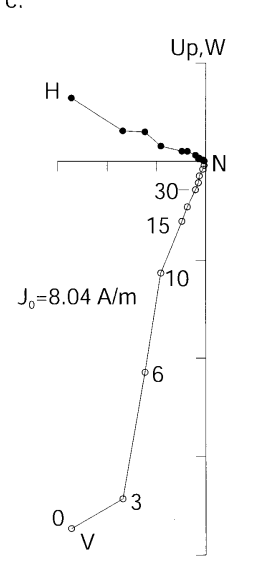

d

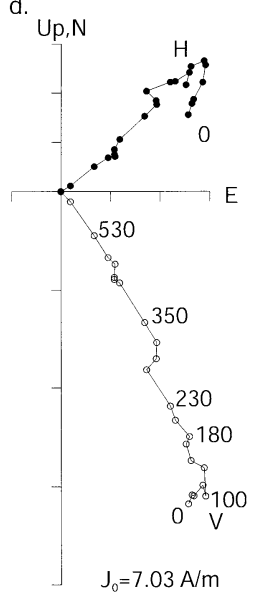

Fig. 2. (a,b) Characteristic behavior of samples of Site 1138 during alternating field and thermal demagnetization, respectively. The orthogonal vector diagrams [55] show nearly univectorial decay to the origin after the removal of a small viscous overprint. Temperature steps and field steps are 50$25^{\circ} \mathrm{C}$ and $2-5 \mathrm{mT}$, respectively. Sample identifications following conventions of the ODP are as follows: (a) 183-1138A80R-2, 114-116 cm; (b) 183-1138A-80R-3, 40-42 cm. V: vertical component; $\mathrm{H}$ : horizontal component; $J_{0}$ : starting magnetization. (c) Alternating field demagnetization of sample 183-1140A-37R-4, 16-18 cm from Site 1140, showing a magnetization less hard than samples of Site 1138 (a). (d) Thermal demagnetization of sample 183-1140A-33R-2, 104-106 cm from Site 1140 showing a rather large viscous component, which, however, could be easily removed after heating to $120^{\circ} \mathrm{C}$. 
from the recovered basalt cores and analyzed in the Paleomagnetic Laboratory at the University of Munich, Germany. Overlying sediments have not been used for paleolatitude analysis because of damaged and highly disturbed cores due to the rotary drilling technique. Most of the samples were subjected to detailed thermal demagnetization. Some samples were also demagnetized using stepwise alternating field treatment in increments of 3-20 mT. Thermal and alternating field results are consistent (Fig. 2). During both demagnetization techniques, the samples show a univectorial decay after the removal of a small viscous magnetization (Fig. 2a,b for Site 1138; Fig. 2c,d for Site 1140), allowing calculation of a characteristic direction with principal component analysis.

All the ChRMs of samples of Site 1138 have a negative inclination. Assuming a southern hemisphere origin, the negative inclinations denote normal polarity. We did not recover sufficient oriented material in lithologic Units 15 and 18 of Site 1138 to obtain reliable paleomagnetic directions. Lithologic Unit 1 of Site 1140 has a negative inclination, followed by positive inclinations downhole in Unit 2-6. Unit 4 consists of a $\sim 1 \mathrm{~m}$ thick layer of dolomitized nannofossil chalk. Two other thin calcareous-dolomitic sedimentary interbeds are between basalt flows at the Unit 2-3 and Unit 5-6 boundaries. We subdivided lithologic Unit 6, which consists of several pillow lava sequences, into four paleomagnetic subunits, based on directional grouping.

Rock magnetic studies on igneous rocks from Leg 183 basement sites have been conducted [13]. The magnetic properties of basalts from Sites 1138 and 1140 are controlled mainly by titanomagnetite. The magnetic minerals vary in size, but most fall within the pseudo-single-domain size range of $0.2-14 \mu \mathrm{m}$ [13]. The generally good magnetic stability and other properties exhibited by titanomagnetite-bearing rocks support the reliability for our studies.

Mean inclinations versus depth are plotted in Fig. 3. Mean-site inclinations have been calculated after [14]. For Site 1138 we obtained a mean inclination of $-62.3^{\circ}\left(\alpha_{95}=4.2^{\circ}, k=63\right)$ and for Site 1140 a mean inclination of $55.3^{\circ}$ $\left(\alpha_{95}=7^{\circ}, k=69\right)$. In Table 1 results are listed.
Table 1

New paleomagnetic results from the CKP (ODP Site 1138) and NKP (ODP Site 1140)

\begin{tabular}{|c|c|c|c|c|}
\hline $\begin{array}{l}\text { Unit num- } \\
\text { ber }\end{array}$ & $\begin{array}{l}\text { Sample } \\
\text { number } \\
n / N\end{array}$ & $\begin{array}{l}\text { Mean flow } \\
\text { inclination }\end{array}$ & $k$ & $\alpha_{95}$ \\
\hline \multicolumn{5}{|l|}{ Site 1138} \\
\hline 2 & $7 / 7$ & -65.0 & 691 & 2.4 \\
\hline 3 & $9 / 9$ & -62.3 & 392 & 2.7 \\
\hline 4 & $6 / 6$ & -61.5 & 654 & 2.9 \\
\hline 5 & $9 / 8$ & -60.2 & 937 & 1.9 \\
\hline 6 & $7 / 7$ & -54.6 & 682 & 2.5 \\
\hline 7 & $9 / 8$ & -53.2 & 664 & 2.2 \\
\hline 8 & $6 / 6$ & -62.6 & 144 & 6.2 \\
\hline 9 & $12 / 10$ & -68.3 & 306 & 2.8 \\
\hline 10 & $10 / 10$ & -73.0 & 371 & 2.5 \\
\hline 11 & $6 / 6$ & -73.5 & 2344 & 2.5 \\
\hline 12 & $7 / 7$ & -71.9 & 671 & 2.5 \\
\hline 13 & $16 / 16$ & -68.3 & 141 & 3.0 \\
\hline 14 & $11 / 10$ & -64.0 & 154 & 3.9 \\
\hline 15 & $0 / 0$ & - & - & - \\
\hline 16 & $3 / 3$ & -60.3 & 82 & 22.7 \\
\hline 17 & $5 / 5$ & -52.5 & 130 & 7.8 \\
\hline 18 & $1 / 0$ & - & - & - \\
\hline 19 & $6 / 6$ & -56.0 & 187 & 5.4 \\
\hline 20 & $7 / 7$ & -51.4 & 92 & 6.7 \\
\hline 21 & $7 / 7$ & -55.1 & 80 & 7.2 \\
\hline 22 & $7 / 6$ & -53.8 & 171 & 5.7 \\
\hline \multicolumn{5}{|l|}{ Site 1140} \\
\hline 1 & $15 / 13$ & -48.5 & 115 & 3.8 \\
\hline 2 & $4 / 4$ & 53.0 & 5466 & 1.6 \\
\hline 3 & $8 / 8$ & 50.2 & 532 & 2.5 \\
\hline 4 & 4 & - & - & - \\
\hline 5 & $13 / 7$ & 49.4 & 1023 & 2.0 \\
\hline $6 a$ & $15 / 14$ & 65.9 & 90 & 4.1 \\
\hline $6 b$ & $6 / 6$ & 60.6 & 638 & 2.9 \\
\hline $6 c$ & $8 / 7$ & 49.1 & 334 & 3.5 \\
\hline $6 \mathrm{~d}$ & $7 / 7$ & 61.7 & 198 & 4.6 \\
\hline
\end{tabular}

\subsection{Paleosecular variation}

The recording of paleosecular variation in lava is a tool for evaluating the quality of a paleomagnetic direction. The GAD takes no account of secular variation, although its effect must be averaged out before paleomagnetic measurements are said to conform with the model. Recordings of the secular variation as a function of age and of latitude, observed from lava flows, have been published [15]. To obtain reliable paleomagnetic directions, the sampled lava flows must be timeindependent and must cover a certain time span 
a.

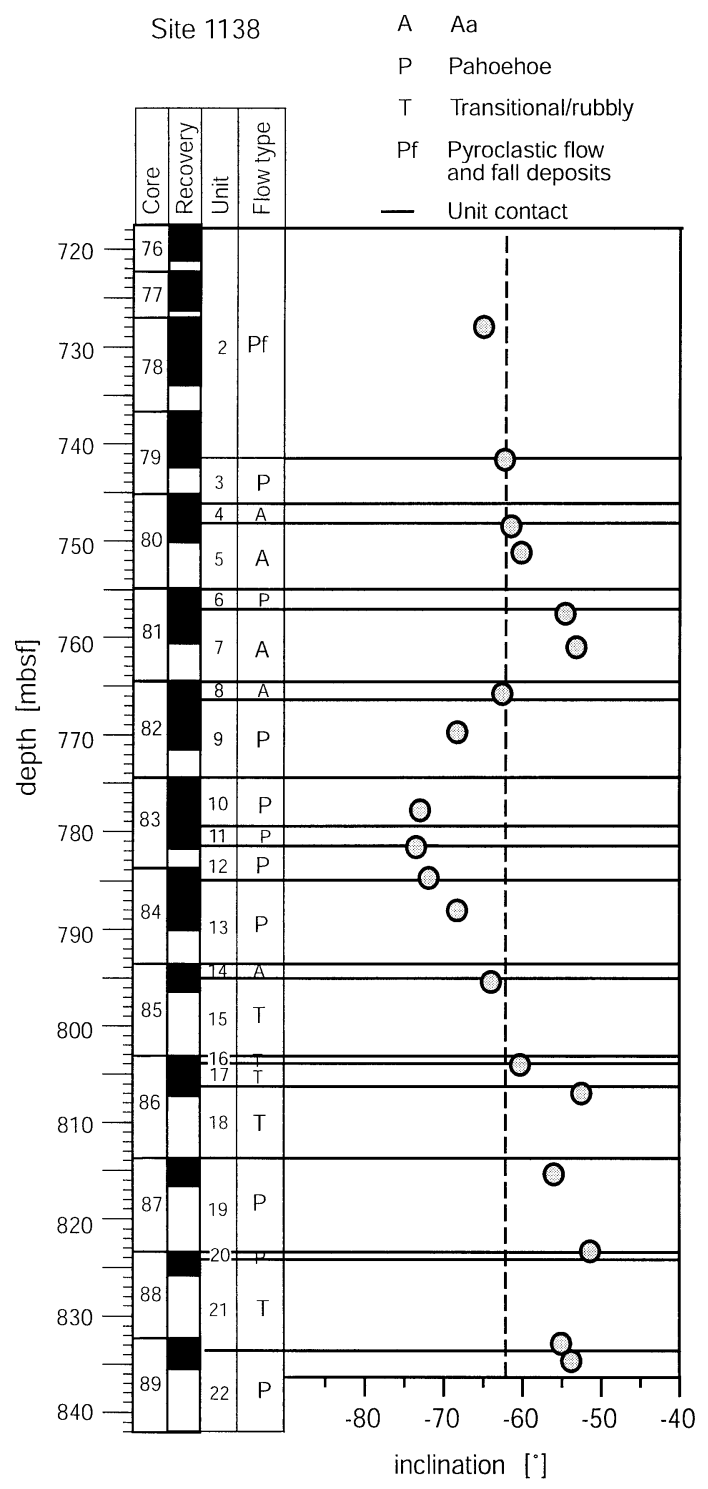

b.

Site 1140

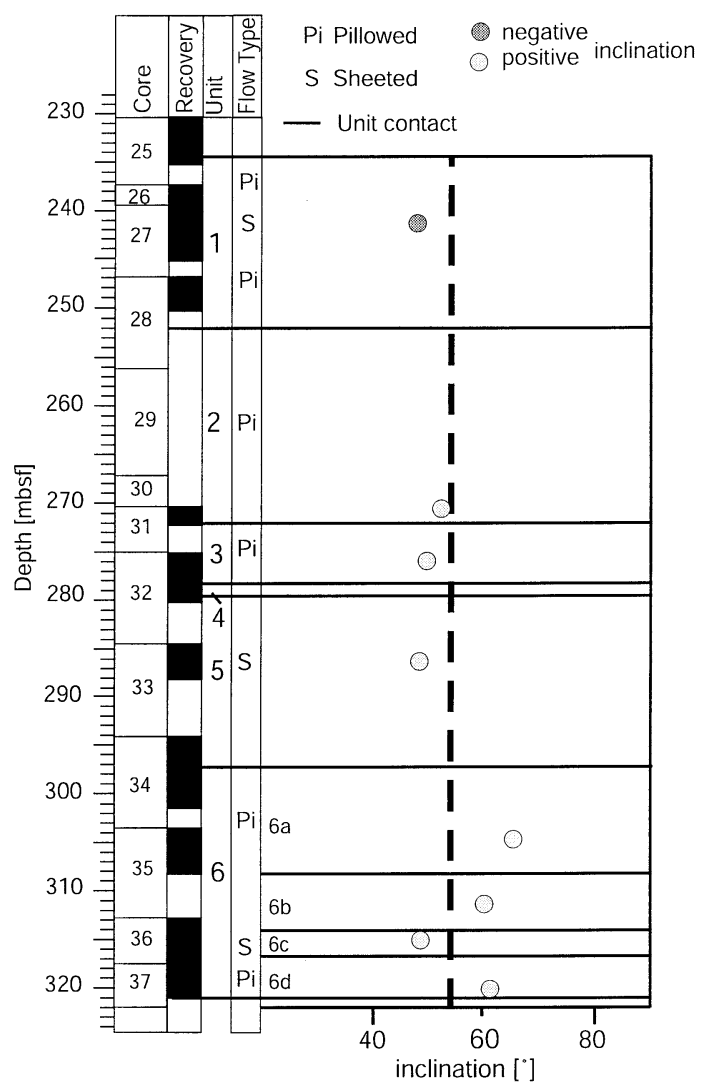

Fig. 3. Mean inclinations from Site 1138 (a) and 1140 (b) versus depth. Mean inclinations for lava flows are represented by gray filled circles and the mean inclination of the sites by the dotted lines (Site 1138: $-62.3^{\circ}, \alpha_{95}=4.2^{\circ} ;$ Site $_{1140:}-55.3^{\circ}$, $\alpha_{95}=7.0^{\circ}$ ). Also shown are recovery and lava type.

of some thousands of years. One way to control this is to compare the angular dispersion of the sampled lava sequence with the data base [15]. The directional angular dispersion was estimated when calculating the mean site inclinations [14], was corrected by the within-site scatter [16], and transformed into pole space [16] for comparison with the global data set. The dispersion of virtual geomagnetic poles from global igneous rocks is available for several time windows. The $80-110$ Ma window is needed to compare dispersion of Site 1138 (Fig. 4a) and the 22.5-45 Ma window 
for comparison with Site 1140 (Fig. 4b). Confidence limits for the angular dispersion for Sites 1138 and 1140 are determined [17].

The angular dispersion is indistinguishable from the predicted virtual geomagnetic pole scatter for Site 1138 (Fig. 4a). A geological argument for time lapse between the single lava events is the oxidized unit boundaries found in the lava flows of Site 1138. They suggest subaerial weathering between the eruptions, which only can take place if a considerable time passed [11].

For Site 1140 the dispersion is less than predicted (Fig. 4b) and hence, paleosecular variation might not completely be averaged out.

Another problem in calculating paleosecular variation on lava flows is the sporadic nature of volcanic activity. During high activity it is possible that several flows are extruded within a very short period of time and therefore they record the same geomagnetic field. This serial correlation may lead to incorrect estimates of the angular dispersion. To avoid this problem similar directions of consecutive flows are often combined in directional groups. Forming directional groups of units 3, 4, 5 and 6, 7 and 8, 9 and 10, 11 in Site 1138 lead to very similar results as calculations
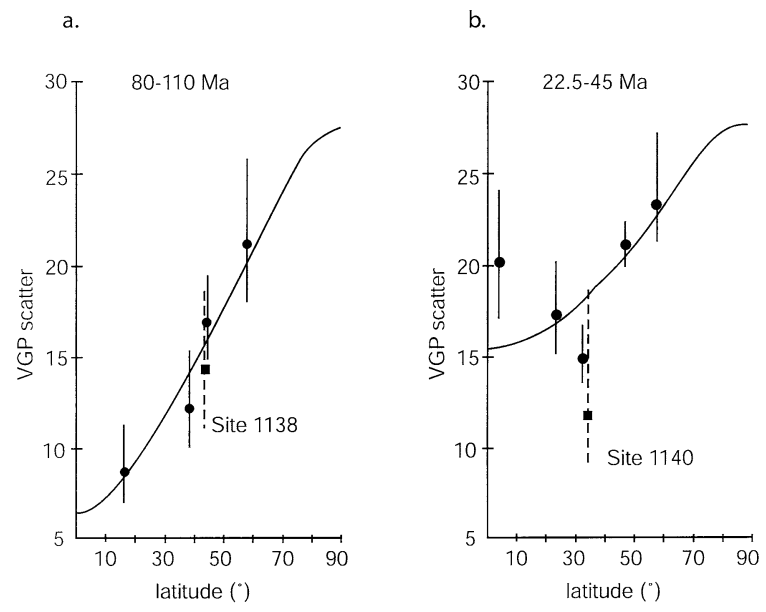

Fig. 4. Comparison of the dispersion of the mean direction of (a) Site 1138 and (b) Site 1140, shown as squares, with data taken from a global data bank [15], for the corresponding time intervals. The dispersion of the mean direction of Site 1138 corresponds to the dispersion of data of similar latitude and age. This indicates a complete averaging out of paleosecular variation. without directional grouping do (inclination $=$ $\left.-62.0^{\circ}, \alpha_{95}=5.7^{\circ}, k=54\right)$.

In Site 1140 units are separated by sediment layers and $\alpha_{95}$ limits are almost not overlapping. We conclude that there is probably no serial correlation between the lava units.

\subsection{Paleolatitudes}

Seismic investigations prior to Leg 183 indicate that geological structure and seismic stratigraphy are relatively simple in the vicinity of Sites 1138 and 1140 [11], and probably no tectonic tilting occurred in Sites 1138 and 1140 . We refer to the problem of tectonic tilting in Section 4.

For the CKP (Site 1138) we determine a paleolatitude of $43.6^{\circ} \mathrm{S}\left(\max .: 47.8^{\circ} \mathrm{S}\right.$; $\min .: 37.9^{\circ} \mathrm{S}$ ) and for the NKP (Site 1140) of $35.8^{\circ} \mathrm{S}$ (max: $43.0^{\circ} \mathrm{S}$; min.: $28.9^{\circ} \mathrm{S}$ ), slightly discordant from the estimated present-day latitude of the Kerguelen hotspot at $49^{\circ} \mathrm{S}$.

\subsection{Previous paleomagnetic investigations}

So far, paleomagnetic investigations on basalts produced by the Kerguelen hotspot have been performed on the Kerguelen Island, on the Ninetyeast Ridge during ODP Leg 121, on the southern Kerguelen Plateau during ODP Leg 120 and on the Rajmahal Trap basalts in northeastern India. Table 2 summarizes locations and calculated mean directions. One problem with data from Kerguelen Plateau is local tectonic tilting. This issue will be addressed in Section 4.

The most recent paleolatitude determination comes from Kerguelen Island, where 32 dated lava flows have been paleomagnetically investigated and the results combined with previously published data [18]. For the mean direction from 59 lava flows with ages between 20 and $22 \mathrm{Ma}$ an inclination $I=-65.5^{\circ}$ and a corresponding paleolatitude of $47.7^{\circ} \mathrm{S}$ have been obtained.

During Leg 121 of the ODP basaltic basement was drilled along the Ninetyeast Ridge. Eight basalt flows (total thickness of $78 \mathrm{~m}$ ) were sampled at Site 756 in the southern part of the Ridge which have an age of $43 \mathrm{Ma}$ and a mean inclina- 
Table 2

Summary of paleolatitudes determined from characteristic inclinations of basaltic lava flows in previous studies for the Kerguelen Plateau, the Rajmahal Traps and the Ninetyeast Ridge

\begin{tabular}{|c|c|c|c|c|c|c|c|c|c|c|c|}
\hline Location & (Ma) & $\begin{array}{l}\text { Inclina- } \\
\text { tion } \\
\left({ }^{\circ}\right)\end{array}$ & $\mathrm{Inc}_{\max }$ & $\mathrm{Inc}_{\min }$ & $\begin{array}{l}\text { Number } \\
\text { of flows } \\
\text { or sites }\end{array}$ & $\left({ }^{\circ}\right)$ & Precision & $\begin{array}{l}\text { Paleolatitude } \\
\left({ }^{\circ} \mathrm{S}\right)\end{array}$ & $\begin{array}{l}\text { Paleolat }_{\max } \\
\left({ }^{\circ} \mathrm{S}\right)\end{array}$ & $\begin{array}{l}\text { Paleolat }_{\text {min }} \\
\left({ }^{\circ} \mathrm{S}\right)\end{array}$ & Reference \\
\hline Rajmahal Traps & 117 & -65.0 & -67.5 & -62.5 & 48 & 2.5 & 85 & 47.0 & 50.4 & 43.8 & [21] \\
\hline Kerguelen Plateau 749 & $100-115$ & -62.0 & -66.0 & -58.0 & 5 & 4.0 & 353 & 43.2 & 48.3 & 38.7 & [20] \\
\hline Kerguelen Plateau 748 & 100 & -63.0 & & & 1 & & & 44.5 & & & {$[20]$} \\
\hline Ninetyeast Ridge 758 & 81.9 & -64.0 & -66.9 & -59.6 & 22 & 3.7 & 69 & 45.8 & 49.5 & 40.4 & [19] \\
\hline Ninetyeast Ridge 756 & 43.3 & 62.1 & 66.0 & 57.8 & 8 & & & 43.4 & 48.3 & 38.5 & [19] \\
\hline Kerguelen Island & $20-22$ & -65.5 & -69.9 & -61.1 & 59 & 4.4 & 17 & 47.7 & 53.8 & 42.2 & [18] \\
\hline
\end{tabular}

tion of $I=+62.1^{\circ}$, corresponding to a paleolatitude of $43.3^{\circ} \mathrm{S}$ [19]. Site 758 lies at the northern end of the Ninetyeast Ridge and drilled basement consists of $81.9 \mathrm{Ma}$ old basalts. From the ChRM of the 22 drilled basalt flows (total thickness of $182 \mathrm{~m})$ a mean inclination of $-64^{\circ}$ was determined, which would correspond to a paleolatitude of $45.8^{\circ} \mathrm{S}$. Parts of the basement are suspected to be tilted [19].

Four basement sites (Sites 747-750) were drilled during ODP Leg 120 on the Kerguelen Plateau. The mean inclination from 13 lava flows of Site 747 is $-51^{\circ}$ which is $11^{\circ}$ shallower than the inclinations at Sites 748 and 749 [20]. This shallow inclination is most likely due to northward tilting of the basement at Site 747. The mean inclination of five basalt flows from Site 749 on the southern Kerguelen Plateau is $-62^{\circ}$ which translates into a paleolatitude of $43.2^{\circ} \mathrm{S}$ $\left(+5.1^{\circ},-4.5^{\circ}\right)$. This result is supported by one lava flow of similar age at Site 748 which yields a paleolatitude of $44.5^{\circ} \mathrm{S}$. The paleomagnetic samples from the two flows at Site 750 had unstable magnetizations and no paleolatitude was determined [20].

A detailed paleomagnetic investigation on basalts of the Rajmahal Trap has been carried out and a well constrained mean direction has been obtained [21]. These results were combined with the data from the Rajmahal Traps [22,23], arriving at a mean inclination of $-65^{\circ}$ (paleolatitude $47^{\circ} \mathrm{S}$, $\max : 50.4^{\circ} \mathrm{S}, \min : 43.8^{\circ} \mathrm{S}$ ) based on 48 sites.

\section{Modeling}

In this section we try to explain the apparent southward motion of the Kerguelen hotspot. We therefore compute paleolatitudes of the products of the Kerguelen hotspot due to a combination of both TPW and hotspot motion. For comparison of these modeled paleolatitudes with the paleomagnetically obtained paleolatitudes we need to make sure that the measured inclinations correspond in fact to the paleolatitude of the hotspot. Several volcanological observations indicate that the subaerial flows from Site 1138 are near vent flows [11]: (1) aa and slab pahoehoe flows rarely travel more than a few tens of kilometers from vents, (2) abundant small vesicles indicate that the lavas did not flow far enough for vesicles, which formed at vents, to coalesce, and (3) clasts in some of the welded basal breccias appear to be spatter, which only forms close to vents. The submarine flows from Site 1140 consist of pillow basalts which cool and solidify rather quickly.

\subsection{True polar wander}

TPW is commonly referred to as the rotation of the entire earth with respect to the spin axis [24]. Assuming fixed hotspots, differences between paleomagnetically determined paleolatitudes and those predicted by hotspots can be attributed to TPW. We used two TPW curves [9,10] (Fig. 5) for a prediction of the paleolatitudes of the products of the Kerguelen hotspot, assuming a fixed hot- 


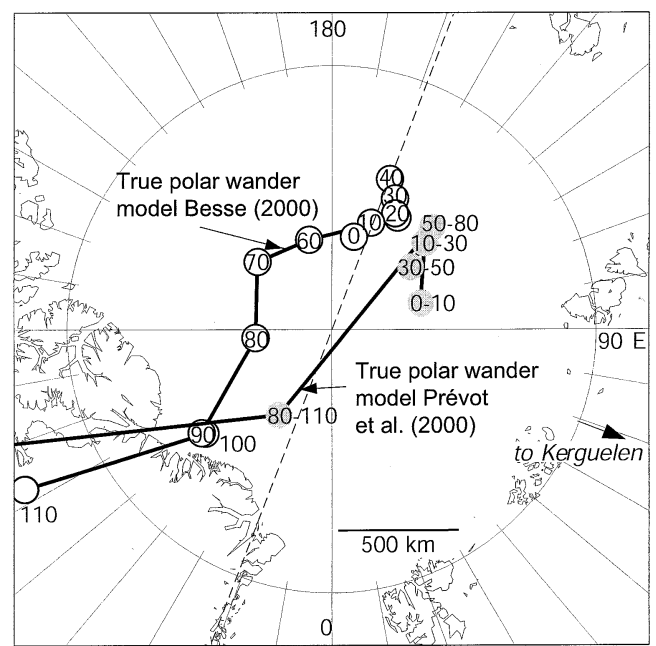

Fig. 5. Polar wander in the hotspot reference frame $[9,10]$. An arrow pointing toward the direction of Kerguelen and a dashed line at a right angle to that arrow are shown. The distances between this dashed line and the polar wander curves approximately show the contributions of polar motion to changes in hotspot paleolatitudes.

spot. Using this assumption, TPW is considered to be the only cause for a difference between the present latitude and the paleolatitudes of the hotspot. With the TPW paths in Fig. 5 an arrow in the direction of the Kerguelen hotspot and a dashed line perpendicular to it are shown. The distances between this dashed line and the polar wander curves approximately show the contributions of polar motion to changes in hotspot paleolatitudes for Kerguelen. For both TPW curves the effect is small until $\sim 100 \mathrm{Ma}$ and significantly bigger for more than $\sim 100 \mathrm{Ma}$. The change in hotspot latitude that would result from these TPW curves alone is shown in Fig. 6 (dashed lines).

These TPW curves were constructed in a 'fixed hotspot' reference frame and thus, strictly speaking, would also have to be modified, if hotspot motions are considered, as will be done in the next section. We have computed the difference between the hotspot reference frame and three different reference frames that take into account the calculated motion of African hotspots [25], and how the TPW curves $[9,10]$, and hence the distance between Kerguelen hotspot and pole would change if this difference is taken into ac- count. We found that in each case, the modifications would lead to predicted hotspot latitudes further south, i.e. would shift the dashed lines in Fig. 6 down. This shift is rather insignificant (no
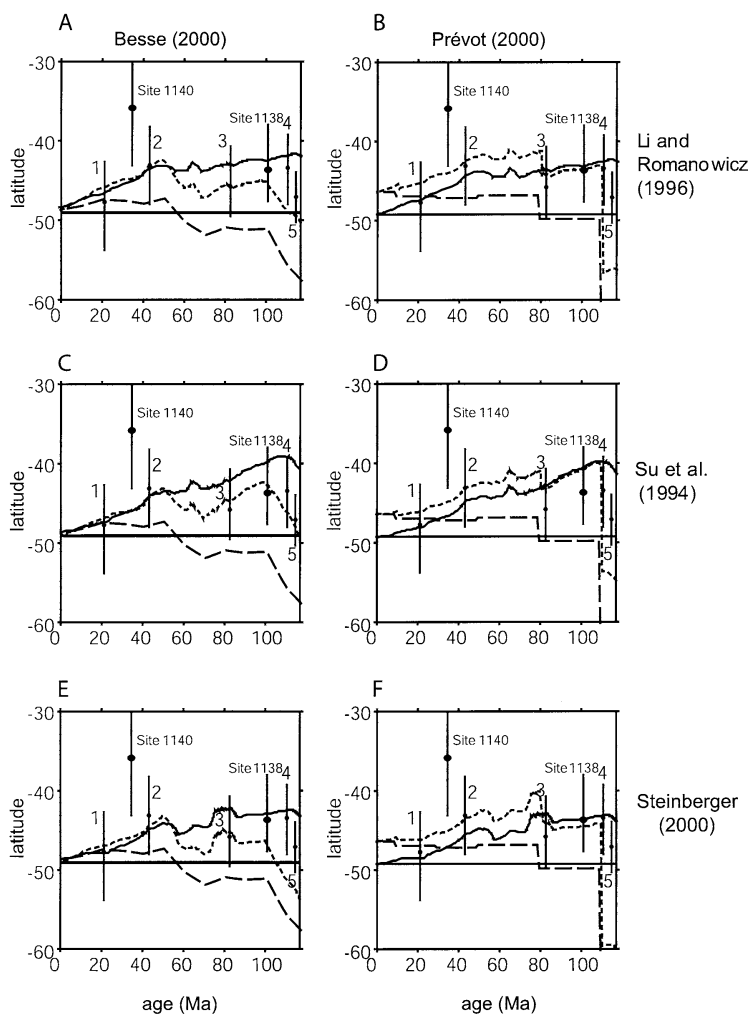

Fig. 6. Predicted and paleomagnetically determined paleolatitudes of the Kerguelen hotspot versus time for the last 120 Myr. The horizontal line at $49^{\circ} \mathrm{S}$ represents the present-day latitude of the hotspot. Vertical black lines show paleolatitudes obtained in previous paleomagnetic investigations (1: Kerguelen Island [18]; 2,3: Ninetyeast Ridge (Leg 121) [19]; 4: southern Kerguelen Plateau (Leg 120) [20]; 5: Rajmahal Traps [21]) and new paleolatitudes of the CKP (Site 1138) and the NKP (Site 1140), presented here. All paleomagnetic latitudes lie farther north than the present location of the hotspot. Dashed lines represent changes in latitude with time due to TPW. Two paleomagnetically determined TPW paths (A,C,E [9]; B,D,F [10]) were used for the calculation. The results would suggest a northward motion of the hotspot since 120 Ma relative to the spin axis, which does not correspond to the paleomagnetic results. Solid lines represents the results of modelling hotspot motion (A,B [36]; C,D [35]; E,F [34]). All three models give a southward motion of the hotspot during the last $117 \mathrm{Myr}$ and hence correspond to the paleomagnetic results. The dotted lines represent the combination of hotspot motion and TPW. 
more than $1.5^{\circ}$ ) for models 1 and 2 , but up to $4^{\circ}$ for model 3. In any case, the modifications increase rather than reduce differences between the paleolatitudes and predicted latitudes, based on TPW alone. Thus, these modifications were not implemented in this paper, because: (1) we want to keep the model simple, (2) they may not cause much difference and (3) they will not affect the conclusion that a significant southward hotspot motion is required to explain the paleolatitudes.

It has also been suggested that the TPW paths track motion of the Tristan hotspot between 90 and 120 Ma rather than TPW [26]. Recently new data have been published [27], which also conflict with the TPW predictions of $[9,10]$. These analysis suggest that the time-averaged position of the spin axis has deviated by no more than $\sim 5^{\circ}$ over the last 130 Myr. In this case, the TPW effect on the hotspot's paleolatitudes would not be significant. In either case, whether we use one of the published (or modified) TPW curves or there has been no significant TPW over the past $130 \mathrm{Ma}$, TPW alone probably cannot explain the differences found between the paleolatitudes and the presumed present-day latitude of the Kerguelen hotspot. We therefore next turn to hotspot motion as the remaining possible explanation.

\subsection{Hotspot motion}

The geodynamic modeling follows a method [2] for estimating the motion of mantle plumes due to large-scale mantle flow. This method, many of the assumptions that go into it, and general features of the results have been previously described in more detail $[2,25,28]$. Therefore only a brief overview is given here.

The computation essentially consists of two steps. In the first step, a large-scale mantle flow field is computed $[29,30]$ based on models of internal density heterogeneities and surface plate motions, assuming a viscous mantle. Here we consider the three radial mantle viscosity structures $[2,25,31]$ shown in Fig. 7 . They are all characterized by a substantial increase of viscosity with depth, as it has been shown $[1,2,25]$ that both a rather low viscosity in the upper mantle and a high viscosity in at least part of the lower mantle

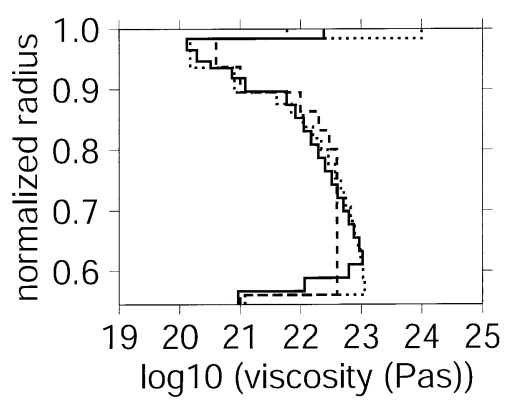

Fig. 7. Three radial viscosity models used in this paper. Dashed line: 'Model A' [28]; dotted line: 'Model B' [2]; continuous line: 'Model C' [31].

are required for a successful model of hotspot motion. The plate motions [32,33], which are a boundary condition for mantle flow, are also based on the assumption of hotspot fixity, and therefore should, in principle, be modified in order to account for hotspot motion. Since hotspot motions tend to be substantially smaller than plate motions, the modifications in plate motions are small compared to the plate motions themselves [28]. Also, because for all the viscosity structures used the plates are somewhat decoupled by a zone of low viscosity from the flow at deeper level, these small changes in plate velocity only lead to very minor changes in flow at mid-mantle depth, which is most responsible for hotspot motion [25]. Therefore, modifications of the plate motion model were not implemented here.

Models of internal density heterogeneities are based on subduction history [34] or seismic tomography anomalies ([35-38]; S. Grand, personal communication), converted to density anomalies, based on mineral physics results [39]. In most cases, internal density heterogeneities derived from seismic tomography are advected back in the flow field for $68 \mathrm{Ma}$ [2], and the flow field is computed for an incompressible mantle without phase boundaries, but we include results for a compressible mantle and a mantle with phase boundaries as well, as described previously [28], using experimentally determined phase boundary parameters $[40,41]$.

In the second step an initially vertical plume conduit is inserted into the mantle. This initial condition is reasonable if conduits are established 
by fast-rising plumeheads [42,43]. Subsequently, the plume conduit is advected and distorted in the large-scale mantle flow, and in addition rises buoyantly. For most models presented, we assume a rising speed $u=1.9 \mathrm{~cm} / \mathrm{yr}$ (for viscosity model A) or $u=0.8 \mathrm{~cm} / \mathrm{yr}$ (for viscosity models B and C) if the viscosity of the surrounding mantle is $10^{21}$ Pas, and that the plume rising speed is inversely proportional to the surrounding mantle viscosity [44]. This is a reasonable assumption [25] for a plume with a comparatively small anomalous mass flux such as Kerguelen [45-47], nevertheless

A

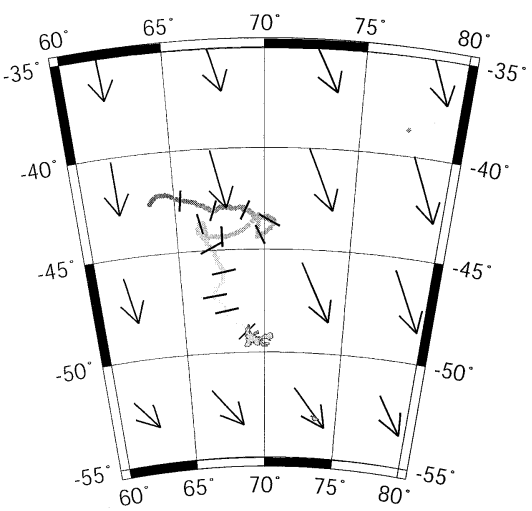

a rather uncertain one. We have therefore also computed results for a number of different buoyant rising speeds. In order to assess the importance of the effect of viscosity inside the conduit increasing with depth [25], we include results for models where the plume radius increases with depth.

For most of the calculations, we assumed the Kerguelen hotspot to be underneath the Kerguelen Island. The present-day position of the hotspot is not well known and it is possibly farther south underneath Heard Island (Fig. 1) or be-
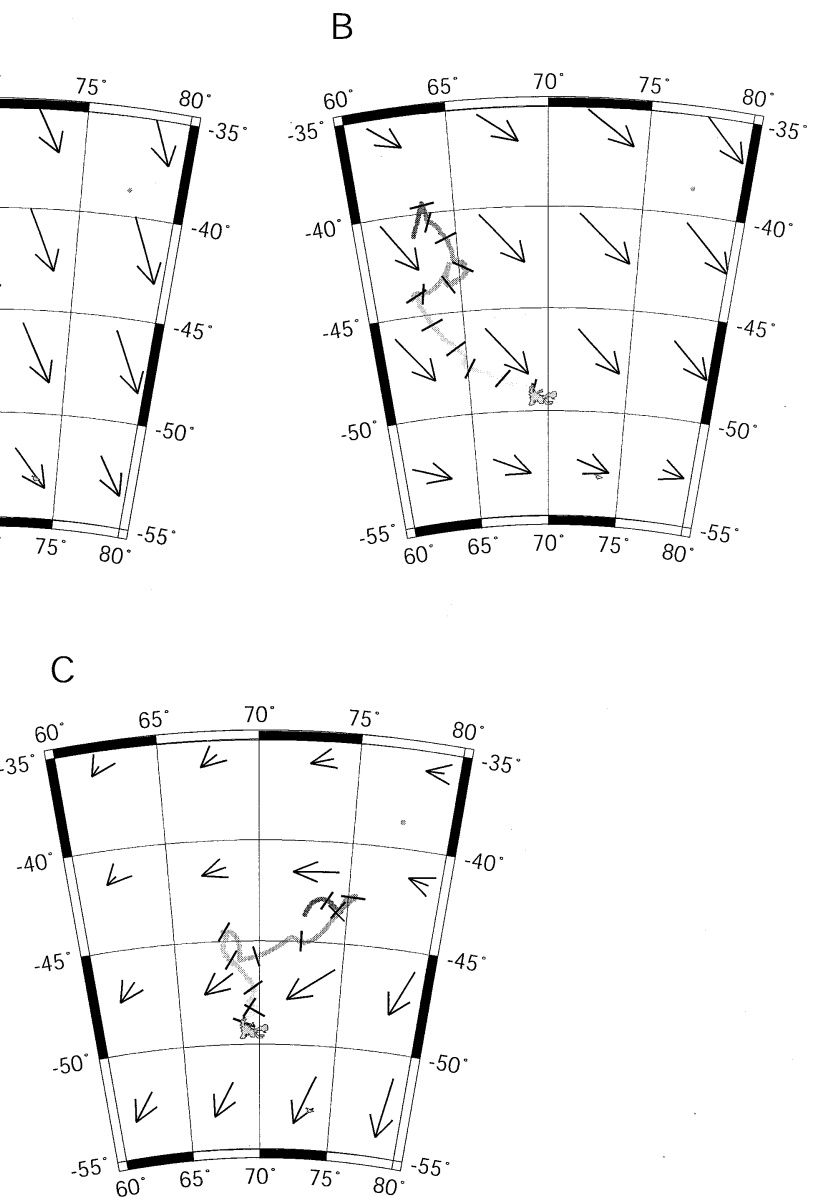

Fig. 8. Calculated drift of the Kerguelen hotspot for the last $117 \mathrm{Myr}$. The density models used to compute mantle flow were derived from seismic tomographic models (A [36]; B [35]) or slab distribution (C [34]). A scaling factor $(\delta \rho / \rho) /\left(\delta v_{\mathrm{s}} / v_{\mathrm{s}}\right)=0.2$ from seismic velocity to density heterogeneities has been used. Shading corresponds to age, i.e. the calculated position of the hotspot $117 \mathrm{Ma}$ ago is shown in dark shading, the supposed present-day position in bright shading, tick marks are made every 10 Ma. All calculations indicate a southward motion of the Kerguelen hotspot. The amounts are $6^{\circ}$ for the slab-dependent density model [34] and the tomographic model of [36] and $9^{\circ}$ for the tomographic model of [35]. Arrows represent the present-day flow of the mantle at a depth of $670 \mathrm{~km} .1^{\circ}$ arrow length $=1 \%$ Ma horizontal flow velocity. 
tween Kerguelen and Heard islands. The position at Kerguelen $\left(49^{\circ} \mathrm{S}\right)$ was chosen for keeping the (then still existing) difference between the paleomagnetic data and the present latitude small; however, we also include results for other assumed plume locations.

Some representative results are shown in Fig. 8. One of the models is the same as in [2], two more calculations are based on a second tomographic model and a slab model as input to obtain the mantle flow. The three calculations indicate a southward motion of the Kerguelen hotspot between $6^{\circ}$ and $9^{\circ}$ during the past $100 \mathrm{Myr}$, depending on the model used. This corresponds to a hotspot motion in the order of $1 \mathrm{~cm} / \mathrm{yr}$.

Results for a larger number of models are shown in Table 3. Predicted hotspot locations are given for ages determined for Sites 1138 and 1140. With the exception of model runs 31,32 and 34 all other models predict a southward motion of between $0.4^{\circ}$ and $5.7^{\circ}$ during the past 34 Myr and between $3.1^{\circ}$ and $9.9^{\circ}$ during the past $100 \mathrm{Myr}$, and the results shown in Fig. 8 are also within that range. Runs 31 and 32 were computed for a larger scaling factor 0.3 (and hence a faster mantle flow field), and in run 34 velocity anomalies in the upper $220 \mathrm{~km}$ were also converted. Apparently, for these cases, our backward advection procedure does not work well. For example, in run 34 , the lithospheric roots seen by tomography are interpreted as high-density anomalies, and they are located in a low-viscosity zone (as the viscosity structures are meant to represent mantle viscosity within and below oceanic lithosphere), and they are hence advected far from their original location, leading to artefacts in the flow field. For comparison, corresponding cases without advection (33 and 35 ) both give a southward motion within the range of other models. Thus, these outliers show the limitations of our backward advection procedure rather than putting the southward hotspot motion into question, and we disregard them in the following discussion. In all other cases considered (runs 12/13, 15/16, 39/40) results with and without advection are similar, with differences in latitude of no more than $2.2^{\circ}$.

Much of the difference between various model results comes from using different density fields.
With other parameters the same (models $1 / 15 / 36$, $12 / 29 / 42,18 / 39$ ) computed latitudes differ by up to $3.8^{\circ}$. Variations of buoyant rising speed by up to a factor of 10 (models 2-7, 19-24, 43-48) lead to considerable variations of the computed hotspot longitudes (up to $11^{\circ}$ ), yet computed latitudes vary much less. For models $2-7$ at $34 \mathrm{Ma}$ they differ by $3.3^{\circ}$, but in other cases, differences are not more than $2.5^{\circ}$. We will explain this qualitatively in Section 4. Results for models 8, 25 and 49 (corresponding to a plume conduit radius increasing with depth) are also rather similar to the corresponding models with constant plume conduit radius. For different viscosity structures (models 1/12, 15/18/29, 36/39/42), computed latitudes differ by not more than $1.6^{\circ}$. Differences in hotspot location (models 9-11, 26-28, 50-52), cause variations in computed southward motion by no more than $1.2^{\circ}$. Including compressibility and phase boundaries (models 29/30, 31/32, 36/37/ 38) changes results by at most $1.7^{\circ}$.

\section{Discussion}

In Fig. 6 we combine some typical results of hotspot motion with polar motion. Each plot contains three curves, showing changes in latitude due to polar motion (Fig. 5), due to the motion of hotspots (Fig. 8), and due to a combination of both. Results for three mantle density models as input for hotspot motion calculations, and two recent determinations of TPW are shown.

The horizontal lines at $49^{\circ} \mathrm{S}$ represent the assumed present-day latitude of the Kerguelen hotspot. Also shown are paleomagnetically obtained paleolatitudes with error bars (vertical lines). Two of them (Site 1138 and 1140) are new paleomagnetic results presented here. They all are further north than the present hotspot position. It is very unlikely that all sites are tectonically tilted in a way to produce such an offset (Fig. 6). The relatively large discrepancy between the paleolatitude of Site 1140 and the present-day latitude of the hotspot could be caused by ridge-plume interactions. The Southeast Indian Ridge intersected the plume location at approximately $40 \mathrm{Ma}$, at the time the NKP was formed, and subsequently mi- 
Table 3

Parameters and results of numerical model runs, in addition to those where results are displayed in Fig. 8

\begin{tabular}{|c|c|c|c|c|c|c|c|c|c|c|c|c|c|c|}
\hline \# & $\mathrm{TM}$ & $\mathrm{SF}$ & MVM & $u_{0}$ & PVM & $\mathrm{td}$ & $\mathrm{adv}$ & com & $\mathrm{pb}$ & HS0 & HS34 & & HS100 & \\
\hline 1 & 3 & 1 & $\mathrm{~A}$ & 1.9 & 1 & $\mathrm{y}$ & $\mathrm{y}$ & $\mathrm{n}$ & $\mathrm{n}$ & 1 & $69.6 \mathrm{E}$ & $44.8 \mathrm{~S}$ & $70.8 \mathrm{E}$ & $39.7 \mathrm{~S}$ \\
\hline 2 & 3 & 1 & A & 0.9 & 1 & $\mathrm{y}$ & $\mathrm{y}$ & $\mathrm{n}$ & $\mathrm{n}$ & 1 & $68.4 \mathrm{E}$ & $43.3 \mathrm{~S}$ & $67.6 \mathrm{E}$ & $39.1 \mathrm{~S}$ \\
\hline 3 & 3 & 1 & A & 2.8 & 1 & $\mathrm{y}$ & $\mathrm{y}$ & $\mathrm{n}$ & $\mathrm{n}$ & 1 & $70.5 \mathrm{E}$ & $45.3 \mathrm{~S}$ & $72.7 \mathrm{E}$ & $39.9 \mathrm{~S}$ \\
\hline 4 & 3 & 1 & A & 3.8 & 1 & $\mathrm{y}$ & $\mathrm{y}$ & $\mathrm{n}$ & $\mathrm{n}$ & 1 & $71.2 \mathrm{E}$ & $45.7 \mathrm{~S}$ & $74.3 \mathrm{E}$ & $40.1 \mathrm{~S}$ \\
\hline 5 & 3 & 1 & A & 5.7 & 1 & $\mathrm{y}$ & $\mathrm{y}$ & $\mathrm{n}$ & $\mathrm{n}$ & 1 & $71.7 \mathrm{E}$ & $46.2 \mathrm{~S}$ & $75.9 \mathrm{E}$ & $40.4 \mathrm{~S}$ \\
\hline 6 & 3 & 1 & A & 7.6 & 1 & $\mathrm{y}$ & $\mathrm{y}$ & $\mathrm{n}$ & $\mathrm{n}$ & 1 & $72.0 \mathrm{E}$ & $46.5 \mathrm{~S}$ & $76.9 \mathrm{E}$ & $40.5 \mathrm{~S}$ \\
\hline 7 & 3 & 1 & A & 9.5 & 1 & $\mathrm{y}$ & $\mathrm{y}$ & $\mathrm{n}$ & $\mathrm{n}$ & 1 & $72.8 \mathrm{E}$ & $46.6 \mathrm{~S}$ & $78.5 \mathrm{E}$ & $40.4 \mathrm{~S}$ \\
\hline 8 & 3 & 1 & A & 3.0 & 2 & $\mathrm{y}$ & $\mathrm{y}$ & $\mathrm{n}$ & $\mathrm{n}$ & 1 & $71.8 \mathrm{E}$ & $45.4 \mathrm{~S}$ & $74.8 \mathrm{E}$ & $40.0 \mathrm{~S}$ \\
\hline 9 & 3 & 1 & A & 1.9 & 1 & $\mathrm{y}$ & $\mathrm{y}$ & $\mathrm{n}$ & $\mathrm{n}$ & 3 & $72.4 \mathrm{E}$ & $47.0 \mathrm{~S}$ & $74.6 \mathrm{E}$ & $42.3 \mathrm{~S}$ \\
\hline 10 & 3 & 1 & A & 1.9 & 1 & $\mathrm{y}$ & $\mathrm{y}$ & $\mathrm{n}$ & $\mathrm{n}$ & 2 & $74.9 \mathrm{E}$ & $49.6 \mathrm{~S}$ & $77.8 \mathrm{E}$ & $45.6 \mathrm{~S}$ \\
\hline 11 & 3 & 1 & A & 1.9 & 1 & $\mathrm{y}$ & $\mathrm{y}$ & $\mathrm{n}$ & $\mathrm{n}$ & 4 & $67.4 \mathrm{E}$ & $42.5 \mathrm{~S}$ & $67.5 \mathrm{E}$ & $37.4 \mathrm{~S}$ \\
\hline 12 & 3 & 1 & $\mathrm{C}$ & 0.8 & 1 & $\mathrm{y}$ & $\mathrm{y}$ & $\mathrm{n}$ & $\mathrm{n}$ & 1 & $69.2 \mathrm{E}$ & $45.1 \mathrm{~S}$ & $71.6 \mathrm{E}$ & $40.8 \mathrm{~S}$ \\
\hline 13 & 3 & 1 & $\mathrm{C}$ & 0.8 & 1 & $\mathrm{y}$ & $\mathrm{n}$ & $\mathrm{n}$ & $\mathrm{n}$ & 1 & $71.3 \mathrm{E}$ & $46.6 \mathrm{~S}$ & $75.8 \mathrm{E}$ & $43.0 \mathrm{~S}$ \\
\hline 14 & 3 & 1 & $\mathrm{C}$ & 0.8 & 1 & $\mathrm{n}$ & $\mathrm{n}$ & $\mathrm{n}$ & $\mathrm{n}$ & 1 & $73.3 \mathrm{E}$ & $48.1 \mathrm{~S}$ & $76.4 \mathrm{E}$ & $45.2 \mathrm{~S}$ \\
\hline 15 & 4 & 1 & A & 1.9 & 1 & $\mathrm{y}$ & $\mathrm{y}$ & $\mathrm{n}$ & $\mathrm{n}$ & 1 & $66.5 \mathrm{E}$ & $46.6 \mathrm{~S}$ & $64.8 \mathrm{E}$ & $43.4 \mathrm{~S}$ \\
\hline 16 & 4 & 1 & A & 1.9 & 1 & $\mathrm{y}$ & $\mathrm{n}$ & $\mathrm{n}$ & $\mathrm{n}$ & 1 & $70.4 \mathrm{E}$ & $46.1 \mathrm{~S}$ & $70.8 \mathrm{E}$ & $43.7 \mathrm{~S}$ \\
\hline 17 & 4 & 1 & A & 1.9 & 1 & $\mathrm{n}$ & $\mathrm{n}$ & $\mathrm{n}$ & $\mathrm{n}$ & 1 & $70.5 \mathrm{E}$ & $48.0 \mathrm{~S}$ & $68.3 \mathrm{E}$ & $45.4 \mathrm{~S}$ \\
\hline 18 & 4 & 1 & B & 0.8 & 1 & $\mathrm{y}$ & $\mathrm{y}$ & $\mathrm{n}$ & $\mathrm{n}$ & 1 & $65.7 \mathrm{E}$ & $47.7 \mathrm{~S}$ & $66.2 \mathrm{E}$ & $45.0 \mathrm{~S}$ \\
\hline 19 & 4 & 1 & B & 0.4 & 1 & $\mathrm{y}$ & $\mathrm{y}$ & $\mathrm{n}$ & $\mathrm{n}$ & 1 & $65.4 \mathrm{E}$ & $46.6 \mathrm{~S}$ & $64.9 \mathrm{E}$ & $43.3 \mathrm{~S}$ \\
\hline 20 & 4 & 1 & B & 1.2 & 1 & $\mathrm{y}$ & $\mathrm{y}$ & $\mathrm{n}$ & $\mathrm{n}$ & 1 & $66.4 \mathrm{E}$ & $48.0 \mathrm{~S}$ & $67.0 \mathrm{E}$ & $45.5 \mathrm{~S}$ \\
\hline 21 & 4 & 1 & B & 1.6 & 1 & $\mathrm{y}$ & $\mathrm{y}$ & $\mathrm{n}$ & $\mathrm{n}$ & 1 & $66.8 \mathrm{E}$ & $48.1 \mathrm{~S}$ & $67.5 \mathrm{E}$ & $45.7 \mathrm{~S}$ \\
\hline 22 & 4 & 1 & B & 2.4 & 1 & $\mathrm{y}$ & $\mathrm{y}$ & $\mathrm{n}$ & $\mathrm{n}$ & 1 & $68.0 \mathrm{E}$ & $48.3 \mathrm{~S}$ & $68.7 \mathrm{E}$ & $45.9 \mathrm{~S}$ \\
\hline 23 & 4 & 1 & B & 3.3 & 1 & $\mathrm{y}$ & $\mathrm{y}$ & $\mathrm{n}$ & $\mathrm{n}$ & 1 & $68.7 \mathrm{E}$ & $48.2 \mathrm{~S}$ & $69.4 \mathrm{E}$ & $45.8 \mathrm{~S}$ \\
\hline 24 & 4 & 1 & B & 4.1 & 1 & $\mathrm{y}$ & $\mathrm{y}$ & $\mathrm{n}$ & $\mathrm{n}$ & 1 & $69.1 \mathrm{E}$ & $48.2 \mathrm{~S}$ & $70.0 \mathrm{E}$ & $45.8 \mathrm{~S}$ \\
\hline 25 & 4 & 1 & B & 2.1 & 2 & $\mathrm{y}$ & $\mathrm{y}$ & $\mathrm{n}$ & $\mathrm{n}$ & 1 & $68.4 \mathrm{E}$ & $47.6 \mathrm{~S}$ & $68.8 \mathrm{E}$ & $45.3 \mathrm{~S}$ \\
\hline 26 & 4 & 1 & B & 0.8 & 1 & $\mathrm{y}$ & $\mathrm{y}$ & $\mathrm{n}$ & $\mathrm{n}$ & 3 & $67.2 \mathrm{E}$ & 49.9S & $67.9 \mathrm{E}$ & $47.3 \mathrm{~S}$ \\
\hline 27 & 4 & 1 & B & 0.8 & 1 & $\mathrm{y}$ & $\mathrm{y}$ & $\mathrm{n}$ & $\mathrm{n}$ & 2 & $68.9 \mathrm{E}$ & $51.9 \mathrm{~S}$ & $69.5 \mathrm{E}$ & $49.6 \mathrm{~S}$ \\
\hline 28 & 4 & 1 & B & 0.8 & 1 & $\mathrm{y}$ & $\mathrm{y}$ & $\mathrm{n}$ & $\mathrm{n}$ & 4 & $64.2 \mathrm{E}$ & $45.5 \mathrm{~S}$ & $64.4 \mathrm{E}$ & $42.8 \mathrm{~S}$ \\
\hline 29 & 4 & 1 & $\mathrm{C}$ & 0.8 & 1 & $\mathrm{y}$ & $\mathrm{y}$ & $\mathrm{n}$ & $\mathrm{n}$ & 1 & $65.4 \mathrm{E}$ & $47.8 \mathrm{~S}$ & $65.1 \mathrm{E}$ & $44.3 \mathrm{~S}$ \\
\hline 30 & 4 & 1 & $\mathrm{C}$ & 0.8 & 1 & $\mathrm{y}$ & $\mathrm{y}$ & $\mathrm{y}$ & $\mathrm{y}$ & 1 & $66.9 \mathrm{E}$ & $48.6 \mathrm{~S}$ & $66.0 \mathrm{E}$ & $44.9 \mathrm{~S}$ \\
\hline 31 & 4 & 2 & $\mathrm{C}$ & 0.8 & 1 & $\mathrm{y}$ & $\mathrm{y}$ & $\mathrm{n}$ & $\mathrm{n}$ & 1 & $65.4 \mathrm{E}$ & $50.0 \mathrm{~S}$ & $66.5 \mathrm{E}$ & $44.4 \mathrm{~S}$ \\
\hline 32 & 4 & 2 & $\mathrm{C}$ & 0.8 & 1 & $\mathrm{y}$ & $\mathrm{y}$ & $\mathrm{y}$ & $\mathrm{n}$ & 1 & $66.3 \mathrm{E}$ & 51.1S & $66.3 \mathrm{E}$ & $45.1 \mathrm{~S}$ \\
\hline 33 & 4 & 2 & $\mathrm{C}$ & 0.8 & 1 & $\mathrm{y}$ & $\mathrm{n}$ & $\mathrm{n}$ & $\mathrm{n}$ & 1 & $70.3 \mathrm{E}$ & $45.2 \mathrm{~S}$ & $70.4 \mathrm{E}$ & $43.9 \mathrm{~S}$ \\
\hline 34 & 4 & 3 & $\mathrm{C}$ & 0.8 & 1 & $\mathrm{y}$ & $\mathrm{y}$ & $\mathrm{n}$ & $\mathrm{n}$ & 1 & $57.0 \mathrm{E}$ & $51.3 \mathrm{~S}$ & $44.5 \mathrm{E}$ & $56.3 \mathrm{~S}$ \\
\hline 35 & 4 & 3 & $\mathrm{C}$ & 0.8 & 1 & $\mathrm{y}$ & $\mathrm{n}$ & $\mathrm{n}$ & $\mathrm{n}$ & 1 & $68.5 \mathrm{E}$ & $45.3 \mathrm{~S}$ & $66.7 \mathrm{E}$ & $43.7 \mathrm{~S}$ \\
\hline 36 & 5 & 1 & A & 1.9 & 1 & $\mathrm{y}$ & $\mathrm{y}$ & $\mathrm{n}$ & $\mathrm{n}$ & 1 & $67.6 \mathrm{E}$ & $45.8 \mathrm{~S}$ & $65.4 \mathrm{E}$ & $43.4 \mathrm{~S}$ \\
\hline 37 & 5 & 1 & A & 1.9 & 1 & $\mathrm{y}$ & $\mathrm{y}$ & $\mathrm{y}$ & $\mathrm{n}$ & 1 & $67.6 \mathrm{E}$ & $45.9 \mathrm{~S}$ & $65.7 \mathrm{E}$ & $43.4 \mathrm{~S}$ \\
\hline 38 & 5 & 1 & A & 1.9 & 1 & $\mathrm{y}$ & $\mathrm{y}$ & $\mathrm{n}$ & $\mathrm{y}$ & 1 & $67.2 \mathrm{E}$ & $46.3 \mathrm{~S}$ & $64.5 \mathrm{E}$ & $45.1 \mathrm{~S}$ \\
\hline 39 & 5 & 1 & B & 0.8 & 1 & $\mathrm{y}$ & $\mathrm{y}$ & $\mathrm{n}$ & $\mathrm{n}$ & 1 & $67.2 \mathrm{E}$ & $46.4 \mathrm{~S}$ & $66.0 \mathrm{E}$ & $44.5 \mathrm{~S}$ \\
\hline 40 & 5 & 1 & B & 0.8 & 1 & $\mathrm{y}$ & $\mathrm{n}$ & $\mathrm{n}$ & $\mathrm{n}$ & 1 & $69.2 \mathrm{E}$ & $46.2 \mathrm{~S}$ & $69.1 \mathrm{E}$ & $43.7 \mathrm{~S}$ \\
\hline 41 & 5 & 1 & B & 0.8 & 1 & $\mathrm{n}$ & $\mathrm{n}$ & $\mathrm{n}$ & $\mathrm{n}$ & 1 & $71.2 \mathrm{E}$ & $47.6 \mathrm{~S}$ & $69.0 \mathrm{E}$ & $45.6 \mathrm{~S}$ \\
\hline 42 & 5 & 1 & $\mathrm{C}$ & 0.8 & 1 & $\mathrm{y}$ & $\mathrm{y}$ & $\mathrm{n}$ & $\mathrm{n}$ & 1 & $66.4 \mathrm{E}$ & $46.7 \mathrm{~S}$ & $63.7 \mathrm{E}$ & $44.6 \mathrm{~S}$ \\
\hline 43 & 5 & 1 & $\mathrm{C}$ & 0.4 & 1 & $\mathrm{y}$ & $\mathrm{y}$ & $\mathrm{n}$ & $\mathrm{n}$ & 1 & $64.9 \mathrm{E}$ & $45.9 \mathrm{~S}$ & $61.1 \mathrm{E}$ & $44.0 \mathrm{~S}$ \\
\hline 44 & 5 & 1 & $\mathrm{C}$ & 1.2 & 1 & $\mathrm{y}$ & $\mathrm{y}$ & $\mathrm{n}$ & $\mathrm{n}$ & 1 & $67.3 \mathrm{E}$ & $47.0 \mathrm{~S}$ & $65.3 \mathrm{E}$ & $44.9 \mathrm{~S}$ \\
\hline 45 & 5 & 1 & $\mathrm{C}$ & 1.6 & 1 & $\mathrm{y}$ & $\mathrm{y}$ & $\mathrm{n}$ & $\mathrm{n}$ & 1 & $68.0 \mathrm{E}$ & $47.2 \mathrm{~S}$ & $66.4 \mathrm{E}$ & $45.0 \mathrm{~S}$ \\
\hline 46 & 5 & 1 & $\mathrm{C}$ & 2.4 & 1 & $\mathrm{y}$ & $\mathrm{y}$ & $\mathrm{n}$ & $\mathrm{n}$ & 1 & $68.7 \mathrm{E}$ & $47.3 \mathrm{~S}$ & $67.7 \mathrm{E}$ & $45.1 \mathrm{~S}$ \\
\hline 47 & 5 & 1 & $\mathrm{C}$ & 3.3 & 1 & $\mathrm{y}$ & $\mathrm{y}$ & $\mathrm{n}$ & $\mathrm{n}$ & 1 & $69.3 \mathrm{E}$ & $47.5 \mathrm{~S}$ & $68.9 \mathrm{E}$ & $45.2 \mathrm{~S}$ \\
\hline 48 & 5 & 1 & $\mathrm{C}$ & 4.1 & 1 & $\mathrm{y}$ & $\mathrm{y}$ & $\mathrm{n}$ & $\mathrm{n}$ & 1 & $69.6 \mathrm{E}$ & $47.6 \mathrm{~S}$ & $69.6 \mathrm{E}$ & $45.3 \mathrm{~S}$ \\
\hline 49 & 5 & 1 & $\mathrm{C}$ & 2.3 & 2 & $\mathrm{y}$ & $\mathrm{y}$ & $\mathrm{n}$ & $\mathrm{n}$ & 1 & $69.5 \mathrm{E}$ & $47.2 \mathrm{~S}$ & $69.1 \mathrm{E}$ & $45.4 \mathrm{~S}$ \\
\hline 50 & 5 & 1 & $\mathrm{C}$ & 0.8 & 1 & $\mathrm{y}$ & $\mathrm{y}$ & $\mathrm{n}$ & $\mathrm{n}$ & 3 & $68.6 \mathrm{E}$ & $48.8 \mathrm{~S}$ & $66.5 \mathrm{E}$ & $47.3 \mathrm{~S}$ \\
\hline 51 & 5 & 1 & $\mathrm{C}$ & 0.8 & 1 & $\mathrm{y}$ & $\mathrm{y}$ & $\mathrm{n}$ & $\mathrm{n}$ & 2 & $70.6 \mathrm{E}$ & $51.1 \mathrm{~S}$ & $68.7 \mathrm{E}$ & $49.5 \mathrm{~S}$ \\
\hline 52 & 5 & 1 & $\mathrm{C}$ & 0.8 & 1 & $\mathrm{y}$ & $\mathrm{y}$ & $\mathrm{n}$ & $\mathrm{n}$ & 4 & $64.6 \mathrm{E}$ & $44.8 \mathrm{~S}$ & $61.4 \mathrm{E}$ & $42.1 \mathrm{~S}$ \\
\hline 53 & 5 & 2 & $\mathrm{C}$ & 0.8 & 1 & $\mathrm{y}$ & $\mathrm{y}$ & $\mathrm{n}$ & $\mathrm{n}$ & 1 & $65.8 \mathrm{E}$ & $47.3 \mathrm{~S}$ & $62.6 \mathrm{E}$ & $45.0 \mathrm{~S}$ \\
\hline
\end{tabular}


grated further north. A pipeline-like flow from the plume towards the ridge $[48,49]$ could have biased the location of the outcoming magma toward the north. The paleolatitude of Site 1140, however, can also be influenced because the secular variation might not be completely averaged out.

We have shown that TPW $[9,10]$, despite its large uncertainties, cannot explain that difference. Thus it appears that a southward hotspot motion is required to explain the observed paleolatitudes. Our models yield a southward motion of $3-10^{\circ}$. It should, however, be pointed out that for the calculation of the paleolatitudes we assume the Earth magnetic field to be a GAD field. This GAD hypothesis has most recently been questioned by [50,51]. These authors argue for longterm octupole contributions. A long-term octupole contribution would rectify the latitude offset that we observed. The curves in Fig. 6 that take both hotspot and polar motion into account generally give the best fit to the paleomagnetic data.

A southward motion of roughly the required amount is a feature of almost all models of hotspot motion tested. This can be explained qualitatively: the calculated hotspot motion tends to reflect the mantle flow in the mid-mantle zone [25], which is represented in Fig. 8 by arrows. This flow tends to be in a southerly direction in the vicinity of Kerguelen. For the recent past, the flow at mid-mantle depths can be regarded as a superposition of a flow component related to subduction in the Indonesian region, and (if density heterogeneities are inferred from tomography) a component related to a large-scale upwelling under southern Africa. The density anomalies that drive the upwelling under Africa are mostly located in the lower part of the mantle, whereas the density anomalies that drive the downwelling under Indonesia are mostly located in the upper part of the mantle - such is also required by the fact that both are associated with a geoid high $[52,53]$. Hence both the upwelling - mostly in the lower part of the mantle - and the downwelling - mostly in the upper part of the mantle - are associated with an outward flow component at mid-mantle depths. In the vicinity of Kerguelen, these are in a southeasterly resp. southwesterly (see Fig. 8C) direction, providing a qualitative explanation why almost all of our model results feature a southward motion of the Kerguelen hotspot. The outward flow from the subduction zone tends to be at greater depth than the outward flow from the large-scale upwelling. Motion of a plume with larger buoyant rising speed tends to represent flow at deeper levels, hence if a larger buoyant rising speed is assumed, the computed hotspot motion tends to have a larger westward component (or smaller eastward component). The model derived from subduction history only contains the flow component related to subduction, hence the computed hotspot motion is in a southwesterly direction. This qualitative argument should essentially also hold for the more distant past, as there has been a long-lived Thetys subduction zone towards the north of Kerguelen, and a large-scale upwelling beneath Africa may also have been present for a long time, possibly since the breakup of Pangaea.

In addition, the Kerguelen hotspot was for part of its history located under the fast northward

$\leftarrow$

First column: \#= Run number. Second column: TM=tomography model: $3=[37], 4=[38], 5=S$. Grand, unpublished model. Third column: $\mathrm{SF}=$ scaling factors $(\delta \rho / \rho) /\left(\delta v_{\mathrm{s}} / v_{\mathrm{s}}\right)$ to convert seismic velocity to density variations: $1:$ scaling factor 0.2 , only mantle density anomalies below $220 \mathrm{~km}$ depth are included; 2 : scaling factor 0.3 , only mantle density anomalies below $220 \mathrm{~km}$ depth are included; 3: scaling factor 0.2 , all mantle density anomalies are included. Fourth column: MVM $=$ mantle viscosity model see Fig. 7. Fifth column: $u_{0}=$ plume conduit rising speed for a surrounding mantle viscosity of $10^{21}$ Pas in units of $\mathrm{cm} / \mathrm{yr}$. Sixth column: $\mathrm{PVM}=$ plume viscosity model: 1 : viscosity inside plume conduit and plume conduit radius are constant, plume conduit rising speed is inversely proportional to viscosity of the mantle surrounding the conduit; 2: viscosity inside plume conduit and plume conduit radius increase with depth, plume conduit rising speed is inversely proportional to the square root of viscosity of the mantle surrounding the conduit. Seventh column: $t d=$ time-dependent plate motion boundary condition $(y / n)$. Eighth column: $\mathrm{adv}=$ advection of density heterogeneities for $68 \mathrm{Ma}(\mathrm{y} / \mathrm{n})$. Ninth column: com=compressible mantle $(\mathrm{y} / \mathrm{n})$. Tenth column: $\mathrm{pb}=$ phase boundaries $(\mathrm{y} / \mathrm{n})$. Eleventh column: HS0 = assumed present-day hotspot location: $1=$ Kerguelen Island $\left(69.0^{\circ} \mathrm{E} 49.0^{\circ} \mathrm{S}\right)$, $2=$ Heard Island $\left(73.5^{\circ} \mathrm{E} 53.1^{\circ} \mathrm{S}\right), 3=$ half-way between 1 and $2\left(71.2^{\circ} \mathrm{E} 51.0^{\circ} \mathrm{S}\right), 4=$ northwest of $1\left(67.0^{\circ} \mathrm{E} 47.0^{\circ} \mathrm{S}\right)$. Columns 12 and 13: HS34 = computed hotspot location at 34 Ma. Columns 14 and 15: HS100= computed hotspot location at 100 Ma. 
moving Indo-Australian or Indian plate. During these times the kinematic (plate-driven) southward return flow at mid-mantle depths provides an additional component of southward hotspot motion. The relative importance of this effect can be assessed by comparing results with constant present-day flow field, where this effect should be absent or less important, to results with time-dependent plate motions. Comparison of model runs 13/14, 16/17 and 40/41 indicates that this effect contributes between $1.4^{\circ}$ and $1.9^{\circ}$ during the past $34 \mathrm{Myr}$.

\section{Conclusion}

We determined reliable new paleolatitudes for the CKP $\left(43.6^{\circ} \mathrm{S}\right)$ and the NKP $\left(35.8^{\circ} \mathrm{S}\right)$. These paleolatitudes are in agreement with previous paleomagnetic investigations on the Plateau, but in disagreement with the latitude of the Kerguelen hotspot $\left(49^{\circ} \mathrm{S}\right)$. TPW cannot explain this discrepancy. Thus it appears that a southward hotspot motion is required to explain the observed paleolatitudes. Our models for the motion of the Kerguelen hotspot yield a southward motion of $3-10^{\circ}$, depending on the parameters used, and therefore fit the paleomagnetic results. The agreement between the paleomagnetic and the modeling results indicates that indeed the Kerguelen hotspot has moved southward since its first occurrence approximately $120 \mathrm{Ma}$ ago.

\section{Acknowledgements}

This research used samples provided by the Ocean Drilling Program (ODP). ODP is sponsored by the U.S. National Science Foundation (NSF) and participating countries under management of Joint Oceanographic Institutions (JOI), Inc. Financial support and travel funds from ODP/Germany, Project Numbers So72/63-2 and -3 , are gratefully acknowledged. M.A. wants to thank the scientific party and the crew of ODP Leg 183 as well as the Munich Gang. We gratefully acknowledge Jean Besse's supply with handing out his new TPW curve prior to publication.
T. Torsvik and an anonymous reviewer are thanked for their helpful comments on this paper. Some figures were prepared using GMT graphics [54].[R $\boldsymbol{R}]$

\section{References}

[1] M.A. Richards, Hotspots and the case for a high viscosity lower mantle, in: R. Sabadini, K. Lambeck (Eds.), Glacial Isostasy, Sea Level and Mantle Rheology, Kluwer Academic, Dordrecht, 1991, pp. 571-587.

[2] B. Steinberger, R.J. O'Connell, Advection of plumes in mantle flow: implications for hotspot motion, mantle viscosity and plume distribution, Geophys. J. Int. 132 (1998) 412-434.

[3] J.A. Tarduno, R.D. Cottrell, Paleomagnetic evidence for motion of the Hawaiian hotspot during formation of the Emperor seamounts, Earth Planet. Sci. Lett. 153 (1997) 171-180.

[4] T.H. Torsvik, R.D. Tucker, L.D. Ashwal, E.A. Eide, N.A. Rakotosolofo, M.J. De Wit, Late Cretaceous magmatism in Madagascar: paleomagnetic evidence for a stationary Marion hotspot, Earth Planet. Sci. Lett. 164 (1998) 221-232.

[5] R.A. Duncan, Hotspots in the southern oceans - an absolute frame of reference from motion of the Gondwana continents, Tectonophysics 74 (1981) 29-42.

[6] P. Molnar, J. Stock, Relative motions of hotspots in the Pacific, Atlantic and Indian oceans since late Cretaceous time, Nature 327 (1987) 587-591.

[7] S.C. Cande, C.A. Raymond, J. Stock, W.F. Haxby, Geophysics of the Pitman Fracture Zone and Pacific-Antarctic plate motions during the Cenozoic, Science 270 (1995) 947-953.

[8] I.O. Norton, Plate motions in the North Pacific: The 43 Ma nonevent, Tectonics 14 (1995) 1080-1094.

[9] J. Besse, V. Courtillot, Apparent and true polar wander and the geometry of the geomagnetic field in the last 200 million years, J. Geophys. Res. (2002) in press.

[10] M. Prévot, E. Mattern, P. Camps, M. Daignières, Evidence for a $20^{\circ}$ tilting of the Earth's rotation axis 110 million years ago, Earth Planet. Sci. Lett. 179 (2000) 517-528.

[11] M.F. Coffin, F.A. Frey, P.J. Wallace, M. Antretter, N.T. Arndt, J. Barling, F. Boehm, M.K. Borre, H.K. Coxall, J.E. Damuth, H. Delius, R.A. Duncan, H. Inokuchi, L. Keszthelyi, J.J. Mahoney, C.L. Moore, R.D. Mueller, C.R. Neal, K.E. Nicolaysen, M.S. Pringle, D.N. Reusch, P.J. Saccocia, D.A.H. Teagle, V. Wähnert, D.A.M. Weis, S.W. Wise, X. Zhao, Proceedings of the Ocean Drilling Program, Kerguelen Plateau-Broken Ridge, Sites 11351142, Proc. ODP Init. Reports 183, 2000 [CD-ROM].

[12] R.A. Duncan, A time frame for construction of the Kerguelen Plateau and Broken Ridge, J. Petrol. (2002) 11091119. 
[13] X. Zhao, M. Antretter, P. Solheid, H. Inokuchi, Identifying magnetic carriers from rock magnetic characterization of Leg 183 basement cores. Proc. ODP Sci. Results 183 (2002) in press.

[14] P.L. McFadden, A.B. Reid, Analysis of palaeomagnetic inclination data, Geophys. J. R. Astron. Soc. 69 (1982) 307-319.

[15] P.L. McFadden, R.T. Merrill, M.W. McElhinny, S. Lee, Reversals of the Earth's magnetic field and temporal variations of the dynamo families, J. Geophys. Res. 96 (1991) 3923-3933.

[16] M.W. McElhinny, R.T. Merrill, Geomagnetic secular variation over the past 5 m.y, Rev. Geophys. Space Phys. 13 (1975) 687-708.

[17] A. Cox, Confidence limits for the precision parameter $\kappa$, Geophys. J. R. Astron. Soc. 18 (1969) 545-549.

[18] B. Henry, C. Plessard, New palaeomagnetic results from the Kerguelen Islands, Geophys. J. Int. 128 (1997) 73-83.

[19] C.T. Klootwijk, J.S. Gee, J.W. Peirce, G.M. Smith, Constraints on the India-Asia convergence: Paleomagnetic results from Ninetyeast ridge, Proc. ODP Sci. Results 121 (1991) 777-882.

[20] H. Inokuchi, F. Heider, Paleolatitude of the southern Kerguelen Plateau inferred from the paleomagnetic study of upper Cretaceous basalts, Proc. ODP Sci. Results 120 (1992) 89-96.

[21] C.T. Klootwijk, Palaeomagnetism of the - upper Gondwana - Rajmahal traps, northeastern India, Tectonophysics 12 (1971) 449-467.

[22] I. McDougall, M.W. McElhinny, The Rajmahal traps of India - K-Ar ages and palaeomagnetism, Earth Planet. Sci. Lett. 9 (1970) 371-378.

[23] C. Radhakrishnamurthy, Laboratory studies for ascertaining the suitability of rocks for palaeomagnetism, in: S.K. Runcorn (Ed.), Palaeogeophysics, Academic Press, London, 1970, pp. 235-241.

[24] P. Goldreich, A. Toomre, Some remarks on polar wandering, J. Geophys. Res. 74 (1969) 2555-2567.

[25] B. Steinberger, R.J. O'Connell, Effects of mantle flow on hotspot motion, in: M.A. Richards, R.G. Gordon, R.D. van der Hilst (Eds.), The History and Dynamics of Global Plate Motions, Geophys. Monogr. Am. Geophys. Union 121 (2000) 377-398.

[26] J.A. Tarduno, J. Gee, Large-scale motion between Pacific and Atlantic hotspots, Nature 378 (1995) 477-480.

[27] J.A. Tarduno, A.V. Smirnov, Stability of the Earth with respect to the spin axis for the last 130 million years, Earth Planet. Sci. Lett. 184 (2001) 549-553.

[28] B. Steinberger, Plumes in a convecting mantle; models and observations for individual hotspots, J. Geophys. Res. 105 (2000) 11127-11152.

[29] B.H. Hager, R.J. O'Connell, Kinematic models of largescale mantle flow, J. Geophys. Res. 84 (1979) 1031-1048.

[30] B.H. Hager, R.J. O'Connell, A simple global model of plate dynamics and mantle convection, J. Geophys. Res. 86 (1981) 4843-4867.

[31] B. Steinberger, A.R. Calderwood, Mineral physics con- straints on viscous flow models of mantle flow, J. Conf. Abstr. 6 (2001).

[32] R.D. Müller, J.-Y. Royer, L.A. Lawver, Revised plate motions relative to the hotspots from combined Atlantic and Indian Ocean hotspot tracks, Geology 21 (1993) 275278.

[33] C. Lithgow-Bertelloni, M.A. Richards, The dynamics of Cenozoic and Mesozoic plate motions, Rev. Geophys. 36 (1998) 27-78.

[34] B. Steinberger, Slabs in the lower mantle - results of dynamic modelling compared with tomographic images and the geoid, Earth Planet. Sci. Lett. 118 (2000) 241-257.

[35] W.-J. Su, R.L. Woodward, A.M. Dziewonski, Degree 12 model of shear velocity heterogeneity in the mantle, J. Geophys. Res. 99 (1994) 6945-6980.

[36] X.D. Li, B. Romanowicz, Global mantle shear-velocity model developed using nonlinear asymptotic coupling theory, J. Geophys. Res. 101 (1996) 22245-22272.

[37] G. Masters, G. Laske, H. Bolton, A. Dziewonski, The relative behavior of shear velocity, bulk sound speed, and compressional velocity in the mantle: implications for chemical and thermal structure, in: S. Karato (Ed.), Seismology and Mineral Physics, Am. Geophys. Union 117 (2000) 63-87.

[38] J. Ritsema, H.J. Van Heijst, Seismic imaging of structural heterogeneity in Earth's mantle: Evidence for large-scale mantle flow, Sci. Prog. 83 (2000) 243-259.

[39] S. Karato, Importance of anelasticity in the interpretation of seismic tomography, Geophys. Res. Lett. 20 (1993) 1623-1626.

[40] M. Akaogi, E. Ito, A. Navrotsky, Olivine-modified spinelspinel transitions in the system $\mathrm{Mg}_{2} \mathrm{SiO}_{4}-\mathrm{Fe}_{2} \mathrm{SiO}_{4}$ : Calorimetric measurements, thermochemical calculations, and geophysical application, J. Geophys. Res. 94 (1989) 15671-15685.

[41] M. Akaogi, E. Ito, Calorimetric study on majorite-perovskite transition in the system $\mathrm{Mg}_{4} \mathrm{Si}_{4} \mathrm{O}_{12}-\mathrm{Mg}_{3} \mathrm{~A}_{12} \mathrm{Si}_{3} \mathrm{O}_{12}$ : transition boundaries with positive pressure-temperature slopes, Phys. Earth Planet. Inter. 114 (1999) 129-140.

[42] T.B. Larsen, D.A. Yuen, Fast plumeheads: Temperaturedependent versus non-Newtonian rheology, Geophys. Res. Lett. 24 (1997) 1995-1998.

[43] P. vanKeken, Evolution of starting mantle plumes: A comparison between numerical and laboratory models, Earth Planet. Sci. Lett. 148 (1997) 1-11.

[44] M.A. Richards, R.W. Griths, Deflection of plumes by mantle shear flow: Experimental results and a simple theory, Geophys. J. 94 (1988) 367-376.

[45] N. Sleep, Hotspots and mantle plumes: Some phenomenology, J. Geophys. Res. 95 (1990) 6715-6736.

[46] G.F. Davies, Ocean bathymetry and mantle convection, 1, Large-scale flow and hotspots, J. Geophys. Res. 93 (1988) 10467-10480.

[47] J.-G. Schilling, Fluxes and excess temperatures of mantle plumes inferred from their interaction with migrating midocean ridges, Nature 352 (1991) 397-403.

[48] W.J. Morgan, Rodriguez, Darwin, Amsterdam ..., a sec- 
ond type of hotspot island, J. Geophys. Res. 83 (1978) 5355-5360.

[49] M.M. Yale, J. Phipps Morgan, Asthenosphere flow, model of hotspot-ridge interactions: A comparison of Iceland and Kerguelen, Earth Planet. Sci. Lett. 161 (1998) 45-56.

[50] R. Van der Voo, T.H. Torsvik, Evidence for late Paleozoic and Mesozoic non-dipole fields provides an explanation for the Pangea reconstruction problems, Earth Planet. Sci. Lett. 187 (2001) 71-81.

[51] T.H. Torsvik, J. Mosar, E.A. Eide, Cretaceous-Tertiary geodynamics: A North Atlantic exercise, Geophys. J. Int. 146 (2001) 850-867.
[52] Y. Ricard, L. Fleitout, C. Froidevaux, Geoid heights and lithospheric stresses for a dynamic Earth, Ann. Geophys. 2 (1984) 267-286.

[53] M.A. Richards, B.H. Hager, Geoid anomalies in a dynamic Earth, J. Geophys. Res. 89 (1984) 5987-6002.

[54] P. Wessel, W.H.F. Smith, New version of the Generic Mapping Tools released, EOS Trans. Am. Geophys. Union 76 (1995) 329.

[55] J.D.A. Zijderveld, AC demagnetization of rocks: analysis of results, in: D.W. Collinson, K.M. Creer, S.K. Runcorn (Eds.), Methods in Palaeomagnetism, Elsevier, New York, 1967, pp. 254-287. 